International Journal of

Health, Medicine and

Nursing Practice

(IJMMNP)

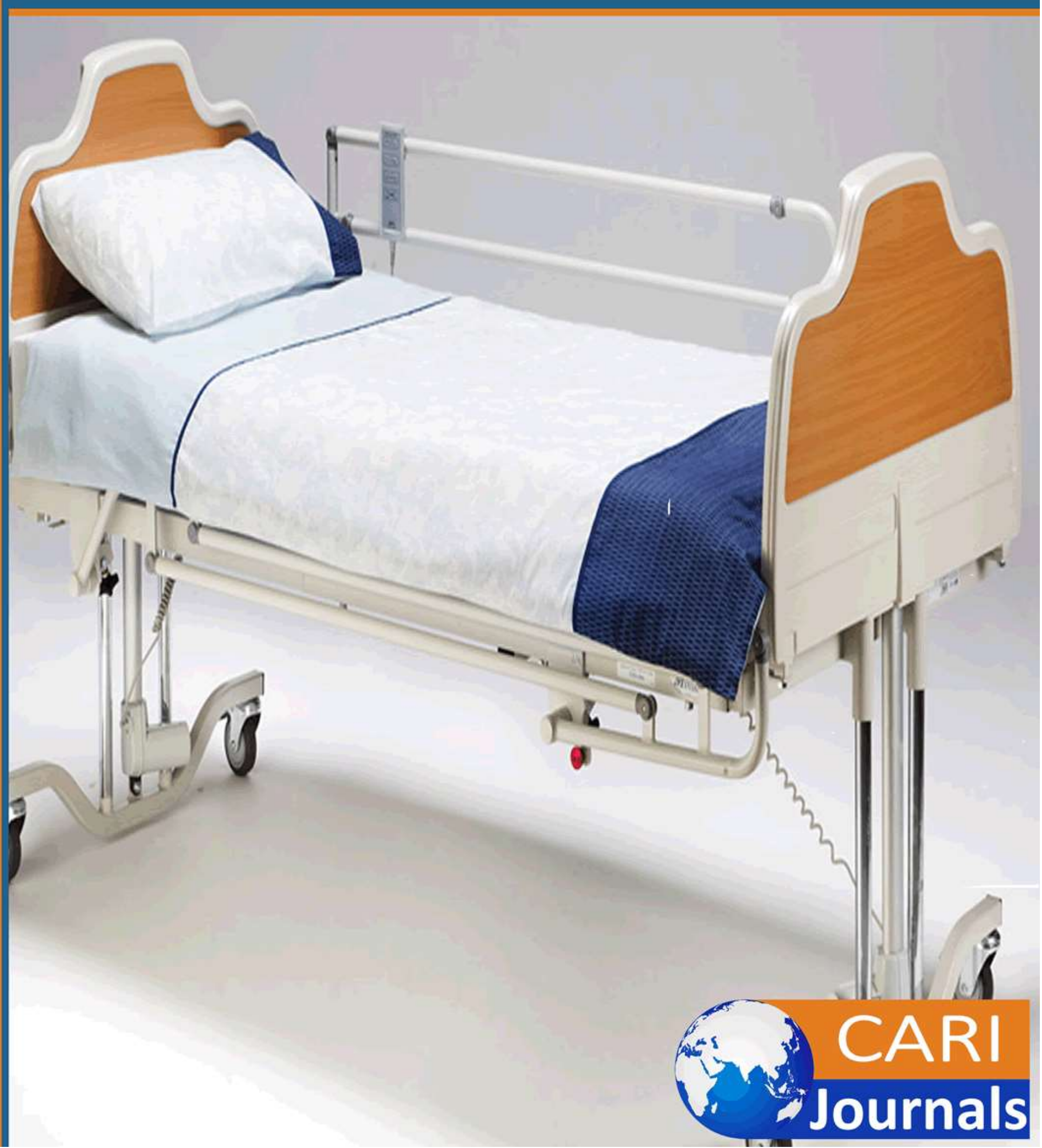




\title{
RADICAL STERNO- COSTAL RESECTION OF SKIN TUMOR AND IMMEDIATE RECONSTRUCTION: A CASE REPORT
}

\author{
$1 *$ Gargadi, S. I \\ 2*Aghaji M. \\ Plastic Surgeon, Cardiothoracic Surgeon \\ Department of Surgery National Hospital Abuja, Nigeria. \\ ${ }^{1}$ Corresponding Author Email: drgargadi@yahoo.co.uk,+234-8033155011 \\ ${ }^{2}$ Corresponding Author Email: macaghaji@yahoo.com, +234-8037909555
}

\begin{abstract}
Purpose: We managed a 30 years old male Albino with Basal Cell Carcinoma of the Sternum with local deep invasion to the Pleura with the aim of offering a cure.

Methodology: Information of the patient from the medical records showed a 30-year-old Albino (Fitzpatrick Skin type I) who was exposed to tropical sun rays for about three decades before presenting with 1-year history of locally advanced sternal skin basal cell carcinoma. This was resected five times in another teaching hospital, but the fungating lesion recurred locally after each attempted local wide excision.

Result: He was found to have $18 \mathrm{~cm} \times 22 \mathrm{~cm}$ malignant ulcer which penetrate over the manubrium and middle of the sternum. It also extended bilaterally to cover the anterior ribs and costochondral joints though his general condition was stable.

Contribution to Theory, Policy and Practice: After detailed investigations and obtaining an informed consent, he had a radical en-bloc resection of the tumor: including the involved sternum and the affected anterior part of the affected pleura. Full thickness reconstruction of the anterior chest wall was done with marlex methacrylate mesh and steel wire support, obliteration of dead space, soft tissue cover with latissimus dorsi pedicle musculocutaneous flap with satisfactory outcome. The use of Stainless wires in our chest reconstruction provided a simpler and cheaper alternative to the use of advanced Tridimensional titanium printed custom made prosthesis, and less morbidity to alternative use of autologous ribs.
\end{abstract}

KEY WORDS: Basal Cell carcinoma, Sternum, Sterno-costal resection, Reconstruction. 

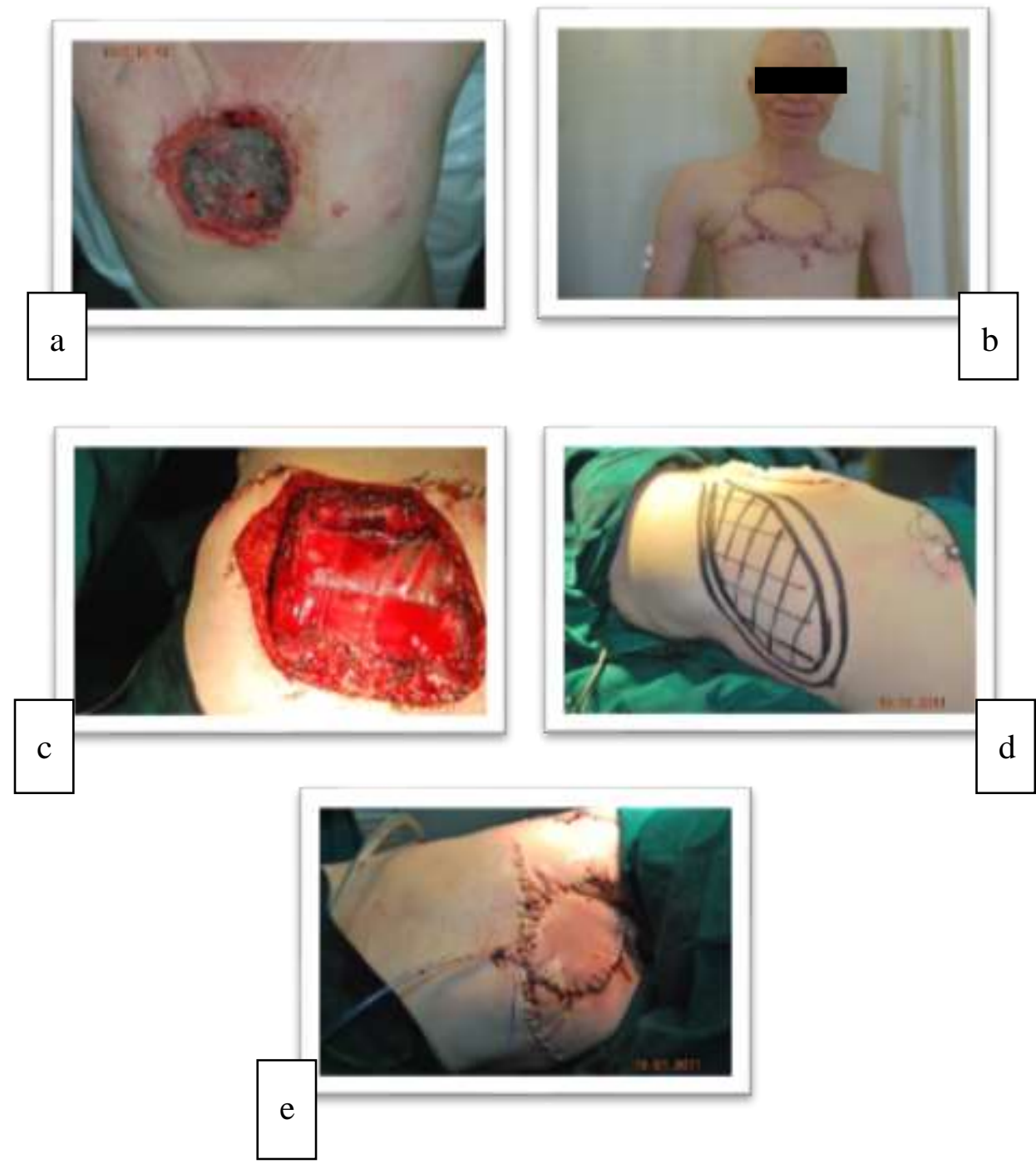

FIGURE 1: EXCISION OF BASAL CELL CARCINOMA AND CHEST RECONSTRUCTION

Slide a: preoperative, b: Post-operative, c: reinforcement of chest wall with marlex methacrylate mesh and stainless-steel wires, $\mathrm{d} \&$ e: Pedicle Latissimus dorsi flap for soft tissue and skin cover.

\section{INTRODUCTION}

The Sternum develops from a pair of Parallel mesenchymal bonds of condensed mesenchyme between $6^{\text {th }}$ to $10^{\text {th }}$ weeks of embryonal life and the ribs are developed from sclerotome cells in the paraxial cells $8^{\text {th }}-10^{\text {th }}$ week of embryonal life. Inspiratory muscles such as sternocleidomastoid muscles and scalene muscles pull the ribcage upwards while the expiratory muscles such as the rectus abdominis, external and internal oblique muscles pull the ribcage downwards. ${ }^{1,2,3}$

Albinism is characterized by absence of melanin due to mutation of gene, which regulates melanin synthesis. It has equal male: female ratio, mostly, autosomal recessive trait. ${ }^{4}$ The skin of an albino is very sensitive to carcinogenic action of ultraviolet B radiation which 
predisposes them to basal cell carcinoma. Ultraviolet radiation induce mutation in the $\mathrm{P}^{53}$ tumor suppressor gene, have been frequently identified in skin cancers. ${ }^{5,6}$ Basal cell carcinoma is locally invasive, rarely metastasize, amenable to surgery and radiotherapy with best result in Moh's micrographic dissection.

This is a case report of an albino who presented with a basal cell carcinoma involving the sternum who had excision and immediate chest reconstruction.

\section{CASE REPORT}

A 30-year-old male albino, who plays guitar, grew up in the tropical climate in a small town of Gudi at Akwanga, Nassarawa State Nigeria without prior knowledge of precautions to take while exposed to sun rays. He presented to us in November 2008 with locally advanced basal cell carcinoma after one year of first appearance of a non-healing malignant ulcer over the skin of his sternum which was excised five times at another teaching hospital but reoccurred.

Bio mimesis has become the objective of the reconstruction strategies after chest wall resection for Primary or Secondary tumors. Bio mimesis is pursued by respecting the anatomy, preserving function, selecting adequate reconstructive materials and integrating multidisciplinary efforts for complex reconstruction. ${ }^{7}$

Patient had both surgical and anesthesiologist preoperative assessment; procedure was done under general anesthesia in supine and left lateral positions. A wide (with $2 \mathrm{~cm}$ of normal surrounding tissue) local excision of mid-sternal tumor was done en-bloc with sternum and anterior part of the affected pleura. Internal mammary vessels were tied using ethibondsutures and divided. The chest wall was reconstructed using marlex methacrylate mesh, stainless steel wires to provide skeletal support and latissimus dorsi pedicle musculocutaneous flap to provide soft tissue and skin cover. Drains were placed in both recipient and donor sites for a week. Conventional histopathological examination of the specimen confirmed basal cell carcinoma and borders where free of tumor. Procedure was tolerated and post-operative condition was satisfactory. Patient was admitted into the intensive care unit for $48 \mathrm{hrs}$ and stayed in the ward for 2 weeks. Wounds healed well with no seroma or infection and the outcome of the procedure was satisfactory. He could play his guitar by the third week. He was followed for a period of 2 years since surgery without local or distant recurrence of tumor and has been symptoms free.

\section{DISCUSSION}

In 1778 Aimar resected Osteosarcoma of the ribs, Cittadiniin 1820 reported; a case of chest wall tumor, and Tansini used predicle latissimus dorsimyocutaneous flap for the coverage of radical mastectomy defect. ${ }^{8,9}$

The use of stainless steel wires in our chest reconstruction provide a simple and satisfactory alternative to the use of autologous ribs or a more advanced Tridimensional titanium printed custom made prosthesis for sterno-costal reconstruction.

A 5-year survival range from $46-66 \%$ for chest wall tumor resection and reconstruction has been reported. ${ }^{10}$

Prevention of basal cell carcinoma in patient with higher risk will require education, use of protective clothing, umbrellas and hats and use of sun protective creams SPF $50^{+}$from childhood. 


\section{CONCLUSION}

Albino (Fitzpatrick skin type I) have higher risk of developing basal cell carcinoma as a result of exposure to ultraviolet rays and often develop skin cancer commonly around the face which is the most sun exposed part of the body. Full thickness anterior chest wall resection with the loss of $>90 \%$ of the sternum leaving a huge defect, Reconstruction was done with marlexmethacrylate mesh, stainless steel wire and latissimus dorsi musculocutaneous predicle flap.

\section{References}

1. Carlson, B. M. Human, Embryology and Developmental Biology. $2^{\text {nd }}$ ed. CH 8. St. Louis: Mosby 1999.

2. Moore, K. L., Persaud, T. V. N., Torchia, M. G. the Developing Human: Clinical oriented Embryology. $9^{\text {th }}$ ed. CH. 14, 16 and 17 Philadelphia: ElsevierSaunders. 2013.

3. Drake R. L., Vagl, A. W., Mitchell A. W. M. Gray's Anatomy for students. $2^{\text {nd }}$ ed. pp 14-26 Philadelphia: Churchill Livingstone 2010.

4. Andrew H, A to Z of Plastic SurgeryPg. 5, 49 \& 272 Oxford University Press 2008.

5. Buzzell RA: Carcinoma of cutaneous malignancies Dermatolsurg 22: 209, 1996.

6. Urano $\mathrm{Y}$, Asano, Yashimoto $\mathrm{K}$. et al. frequent $\mathrm{P}^{53}$ accumulation in the chronically sunexposed epidermis and clonal expansion of $\mathrm{P}^{53}$ mutant cells in the epidermis, adjacent to basal cells carcinoma J invest Dermatol 104: 928, 1995.

7. Gaetano. Rocco M.D Chest Wall Resection and reconstruction According to the principles of Bio mimesis seminars in thoracic and cardiovascular surgery vol. 23, issue 4 pg. 307-313 Elsevier 2011.

8. Olivari, N.: Use of thirty latissimus dorsi flaps. Reconstr. Surg., 64: 6541979.

9. David J, M.D, Azul S. Jaffer, M. D, Chest wall Reconstruction updated: Feb 22, 2016 (Medscape)

10. Chapelier A.R Missana M C. Sternal resection and reconstruction Ann Thorac. Surgery: 77: 1001-1007 2004. 